\title{
Analysis of chitosan treatment on white and black sweet cherry
}

\author{
GABOR ZSIVANOVITS $^{1 *}$ (1), DIDA ISERLIYSKA ${ }^{1}$, MARIA MOMCHILOVA ${ }^{1}$, \\ PETYA SABEVA ${ }^{1}$ and ZARYA RANKOVA ${ }^{2}$
}

\footnotetext{
${ }^{1}$ Institute of Food Preservation and Quality, Plovdiv, Bulgaria

${ }^{2}$ Fruit Growing Institute, Plovdiv, Bulgaria
}

\section{CONFERENCE FULL PAPER}

Received: August 11, 2020 • Accepted: September 20, 2020

Published online: November 20, 2020

(C) 2020 The Author(s)

\section{ABSTRACT}

Bicolor (Rosaline) and black (Regina) sweet cherry cultivars were treated with chitosan-Ca-lactate and chitosan-alginate solutions. The chitosan coating is biocompatible, nontoxic and possesses antimicrobial activity. The sample series (five replicates of thirty pieces from each variety and each treatment, and a control) were refrigerated at $4{ }^{\circ} \mathrm{C}$ for 21 and $28 \mathrm{~d}$, to the end of shelf-life. Physical (visual sorting, weight loss and texture of intact fruit), physicochemical (TSS, antioxidant activity, and $\mathrm{pH}$ of the pulp), and microbiological properties (total number of microorganisms, Escherichia coli, fungi and yeasts) were investigated weekly. For the last week only the Regina cultivar had acceptable appearance, the other cultivar was discarded after $21 \mathrm{~d}$. The chitosan-alginate treatment preserved the texture, showed smaller weight loss, higher antioxidant preservation and smaller microbial contamination than the samples with chitosan-Calactate on both cultivars. Based on the results, the edible coating can help to preserve the nutritional value of fresh fruit and this technology can be useful in preparing the ready-to-eat fruit salads or in decoration of confectionery products.

\section{KEYWORDS}

shelf-life time, physical properties, edible coating, Prunus avium

\footnotetext{
*Corresponding author. E-mail: g.zsivanovits@canri.org
} 


\section{INTRODUCTION}

Fresh fruits are extremely perishable and more susceptible to postharvest spoilage due to high moisture content (80-90\%) limiting the storage period and marketing life and causing high economic losses around the world (Maisnam et al., 2017). The quality of fruits can be maintained but not improved after harvesting; therefore, it is essential to harvest fruits at proper stage and maturity. The edible coating can be one of the tools of sustainable food systems to maintain food quality and safety by reducing postharvest losses. Edible coatings are non-pollutant natural polymers thin wrapping layers on the surface of the food. They serve as a barrier between the food and the environment, during handling, transport and storage. They have functional and/or anti-microbiological effect (García et al., 2014). They are formed from three types of biological materials: hydrocolloids (polysaccharides and proteins), lipids and composite materials. There are different techniques for application of the edible coating on the fruit, such as brushing, dipping or spraying the coating solution on the food surface (Misir et al., 2014). The chitosan is a polysaccharide coating material, produced by deacetylation of chitin (obtained from shrimp, crab and crawfish shells, and mushroom waste). It has functional properties like antimicrobial activity, antioxidant activity, film forming ability, texturizing and binding property. It is one of the widely used coating materials (Lin et al., 2018), which delays ripening and color changing, and reduces ethylene production. Alginate is a water soluble, linear polysaccharide extracted from brown seaweed. Alginate has been reported to be mucoadhesive, biodegradable, and biocompatible gelling or thickening agent. Chitosan can interact ionically with several polyanions, such as alginate (Bellich et al., 2016).

Sweet cherry (Prunus avium L.) is one of the most commercially important Prunus fruit tree species planted in temperate climate zones and in Bulgaria (Malchev \& Zhivondov, 2016; Zhivondov et al., 2011) with high sensitivity for postharvest loss, short ripening and storage period. Sweet cherries are non-climacteric with high transpiration rate and a susceptibility to fungal rots and physiological disorders (Alique et al., 2005). The storage period can be extended with cooling because the sweet cherry is considered to be a non-chilling sensitive fruit (Petriccione et al., 2015).

'Rosalina' cultivar (2009) is one of the first bicolor sweet cherry cultivars from the selection program of Fruit Growing Institute (Plovdiv, Bulgaria). The cultivar 'Rosalina' possesses high and regular productivity and the fruit is resistant to cracking with very consistent pale, yellow mesocarp, uncolored juice and strong acidity (Zhivondov, 2011). 'Regina' is a high-quality, lateseason cherry cultivar that exhibits excellent rain crack resistance. The fruit is very large and firm, with a mild, pleasant flavor (Long et al., 2007).

In this study, the effect of chitosan based edible coatings on the two above mentioned sweet cherry cultivars during storage was evaluated.

\section{MATERIALS AND METHODS}

Fruit from Rosalina and Regina sweet cherry cultivars were harvested for shelf-life experiments from the Fruit Growing Institute - Plovdiv, Bulgaria. Those two varieties ripen more or less at the same time; they were harvested and treated on the same day. The food-grade, water-soluble chitosan (low molecular weight) was purchased from Xi'an Lyphar Biotech Co., LTD, China. Also, the food grade $\mathrm{Ca}$-lactate and the sodium alginate was bought from Sigma Aldrich, Bulgaria. 


\section{Treatments}

All of the fruit were selected without injury and with stalk, were carefully washed and dried before the experiments. Three types of coating solutions were prepared: 1 . chitosan (1\%) -Calactate (1\%), 2. Chitosan (1\%) and 3. Sodium-alginate (1\%) solutions with distillated water. The fruit were immersed for $10 \mathrm{~min}$. to chitosan-Ca-lactate (1\%) solution (Ch-Ca - monolayer threat) or at first to chitosan (1\%), after drying to alginate solution (1\%) for bilayer treat (Ch$\mathrm{Al}$ ), and dried for $10 \mathrm{~min}$. The samples were refrigerated at $4{ }^{\circ} \mathrm{C}$ on opened trays (30 pieces/ tray). 10 trays for each coating variants and control were prepared from both varieties. The physical, physicochemical and microbiological parameters were investigated on one tray (extended to 30 fruits) from all series each week during the storage.

\section{Visual appearance loss}

The damaged (injured, browned or rotted) pieces were selected and the quantity of them is expressed in \% for the trays. All of the trays were allowed for selection at each time.

\section{Weight loss}

The identified fruit were weighed at each experimental date before they were selected for investigation or wasted. The weight loss was calculated as the $\%$ of weight difference compared to the initial weight.

\section{Texture}

Ten fruits from all selected trays were measured with a TAXT2i Texture Analyzer (Stable Micro Systems Ltd, Godalming, UK) using puncture test with cylindrical probe ( $d=5 \mathrm{~mm}$, deformation speed $=1 \mathrm{~mm} / \mathrm{s}$, max. deformation $=8 \mathrm{~mm}$, Aday and Caner, 2010).

The freshness of the sweet cherry characterized by the crunchiness (hard peel and flesh):

$$
\text { Crunchiness }=\frac{F_{f} / F_{r}}{\ell_{f} / \ell_{r}} .
$$

where $F_{f}=$ yield force, $F_{r}=$ rupture force, $\ell_{f}=$ yield deformation, $\ell_{r}=$ rupture deformation.

Third of the fruit from a tray was pitted and meshed to pulp, together with the peel but without the stalk for physicochemical tests and another third for microbiological tests.

Soluble solid content (TSS, ${ }^{\circ}$ Brix) was measured by ABBE type refractometer at $20{ }^{\circ} \mathrm{C}$.

$\mathrm{pH}$ of the pulp was measured by an INOLAB pH 7110 type (RADELKIS, Hungary) $\mathrm{pH}$ meter at $20{ }^{\circ} \mathrm{C}$ in five repetitions. The instrument was calibrated at $\mathrm{pH} 4.0$ and 7.0.

\section{Antioxidant activity}

Total antioxidant activity (TAA) was quantified by the method based on the capacity of different components to scavenge the DPPH radical cation compared to the standard antioxidants (ascorbic acid and Trolox) in a dose response curve. The absorbance at $515 \mathrm{~nm}$ of the extract was measured by spectrophotometer (UVVIS EVOLUTION 201 Thermo Scientific USA). The results are expressed as Trolox equivalent mg/100 g (Arnao et al., 2001).

The total number of microorganisms (TNM - EN ISO 4833-2:2013), the total coliform bacteria (ISO 16649-2:2001) and the total yeasts and molds (TYM - EN ISO 21527-2:2011) were 
measured based on the plate counting method. The results were expressed as a logarithm of colony forming units $\left(\log _{10} \mathrm{cfu} / \mathrm{g}\right)$.

The received data was statistically evaluated for the differences among treatments and storage days by one way ANOVA method. Homogeneity groups of the samples were analyzed based on the significance level of the differences by post hoc Fisher (LSD) test.

\section{RESULTS AND DISCUSSIONS}

\section{Visual appearance loss}

During the storage, the quantity of healthy fruit decreased. That decreasing depends on both the cultivar and the coating. From the cultivar, 'Rozalina' there were not enough healthy fruit left for further experiments after the $22 \mathrm{nd} \mathrm{d}$. The cultivar 'Regina' could be stored for $29 \mathrm{~d}$. To the end of the shelf life time, the appearance of the fruits also changed. Most of the control fruit became wrinkled during $29^{\text {th }} \mathrm{d}$. The treated samples better tolerate the cold storage. The loss of samples among the $\mathrm{Ch}-\mathrm{Al}$ coated fruit was lower than among the $\mathrm{Ch}-\mathrm{Ca}$ coated samples (Fig. 1).

The weight-loss is mainly due to water-loss caused by transpiration and respiration. The sweet cherry has low skin diffusion resistance (Serrano et al., 2005) and high surface/volume ratio (Conte et al., 2009; Wani et al., 2014). During cold storage, coated samples show lower weight loss, because they have lower respiration rates (Bautista-Banos et al., 2006). The delay in weight loss with $\mathrm{Ch}-\mathrm{Al}$ coating was longer than with the $\mathrm{Ch}-\mathrm{Ca}$.

\section{Texture changes}

The fresh sweet cherry fruit have high crunchiness (hard peel and flesh). The crunchiness of the cv. 'Rozalina' was higher during the storage time than that of the cv. 'Regina' (Fig. 2). The Ch-Al treated samples showed higher crunchiness because the ionic complex made the peel stronger and the flesh harder, with high force ionic bindings (Diaz-Mula et al., 2012).

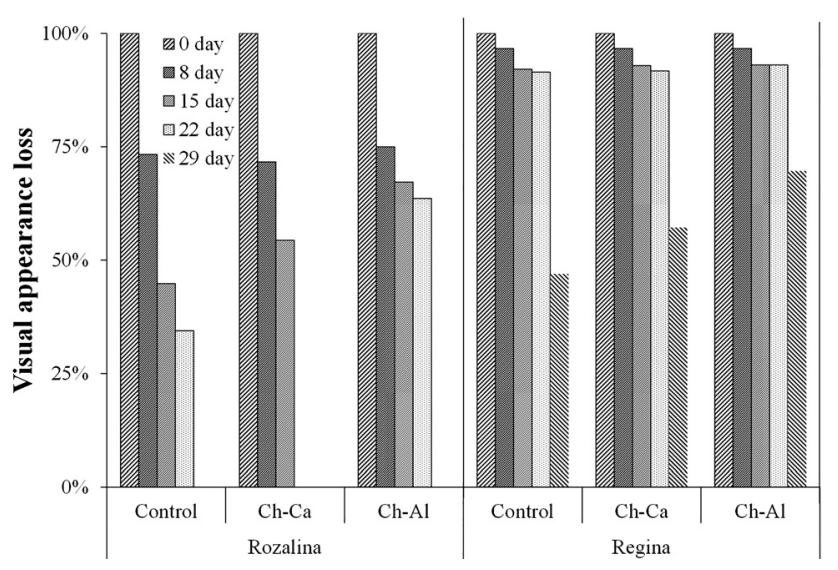

Fig. 1. Visual appearance loss 


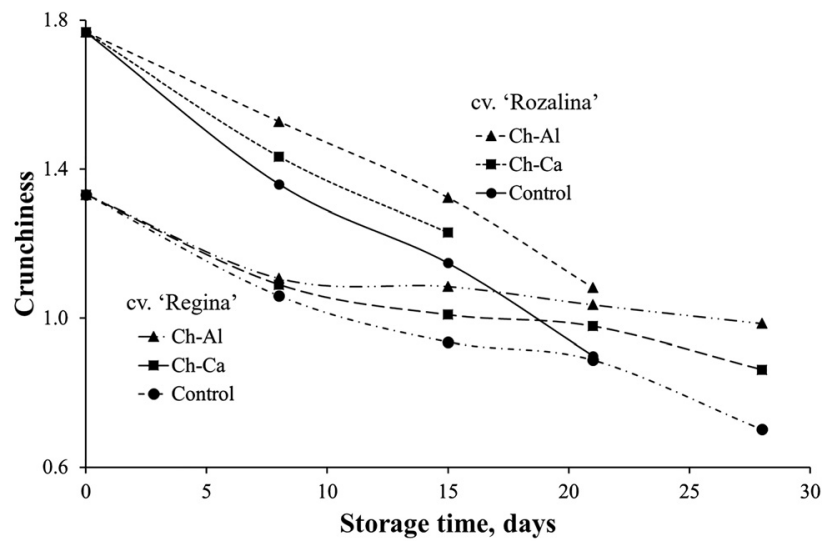

Fig. 2. Crunchiness

\section{Soluble solid content}

The TSS values of the coated and uncoated fruit increased over the $22 \mathrm{~d}$ or $29 \mathrm{~d}$ of cold storage period (Table 1). The increase could be attributed to the breakdown of starch to sugar, to the decrease in respiration rate and conversion of sugars into $\mathrm{CO}_{2}$ and $\mathrm{H}_{2} \mathrm{O}$ (Ghasemnezhad et al., 2011), to the hydrolysis of cell wall polysaccharides (Comabella and Lara, 2013), and to the increase of dry matter due to water loss (Petriccione et al., 2015). The changes are smaller in the coated samples, because the coatings modified the internal atmosphere, reduced the respiration activity and the water-loss (Dong et al., 2004, Zsom et al., 2016). According to our results, the Ch-Ca coating is slightly better in the preservation of the TSS than the Ch-Al treatment.

\section{$\mathrm{pH}$}

The chitosan based coatings reduced $\mathrm{pH}$ increasing significantly during the shelf life (Table 1). The higher acidity loss in uncoated fruit could be explained by respiratory metabolism (DiazMula et al., 2012). The acidity loss was smaller with bilayer $\mathrm{Ch}$-Al coating maybe due to the smaller weight-loss. Lower acidity loss with chitosan and/or alginate based coatings are reported for different fruits in the literature as well (strawberry, guava, and litchi by Dong et al., 2004; Hernandez-Munoz et al., 2008; Hong et al., 2012).

\section{Antioxidant activity}

The sweet cherry is a very good source of natural antioxidants (Ferretti et al., 2010). Chitosan based coatings delay the fruit senescence that is associated to enzymatic and non-enzymatic antioxidant systems (Usenik et al., 2008). The antioxidant activity is much higher for the 'Regina', but the decrease is smaller for the 'Rozalina' (Table 1). The shown cultivar dependence is known from other studies as well (Pasquariello et al., 2015). The results obtained show how the coatings delay the decreasing of the antioxidant activity. The reducing effect of the $\mathrm{Ch}-\mathrm{Al}$ bilayer coatings is higher than the Ch-Ca. 
Table 1. Result of physico-chemical and microbiological properties

\begin{tabular}{|c|c|c|c|c|c|c|c|}
\hline Cultivar & Treat & $d^{*}$ & TSS, ${ }^{\circ}$ Brix & TAA, mg/100 g & $\mathrm{pH}$ & $\begin{array}{c}\text { TNM, } \\
\log _{10} \mathrm{cfu} / \mathrm{g}\end{array}$ & $\begin{array}{c}\text { TYM } \\
\log _{10} \mathrm{cfu} / \mathrm{g}\end{array}$ \\
\hline \multirow[t]{11}{*}{ 'Rozalina' } & Cont. & 0 & $15.6 \pm 0.10^{\mathrm{a}}$ & $2,207.10 \pm 0.42^{\mathrm{d}}$ & $3.68 \pm 0.03^{\mathrm{a}}$ & $4.67 \pm 0.35^{\mathrm{a}}$ & $3.22 \pm 0.15^{\mathrm{a}}$ \\
\hline & Cont. & 8 & $16.0 \pm 0.05^{\mathrm{b}, \mathrm{y}}$ & $2,170.88 \pm 0.33^{c, z}$ & $3.92 \pm 0.03^{\mathrm{b}, \mathrm{z}}$ & $5.22 \pm 0.48^{\mathrm{ab}, \mathrm{y}}$ & $3.50 \pm 0.18^{\mathrm{ab}, \mathrm{z}}$ \\
\hline & Cont. & 15 & $17.5 \pm 0.05^{\mathrm{c,y}}$ & $2,121.76 \pm 0.44^{\mathrm{b}, \mathrm{z}}$ & $4.02 \pm 0.04^{\mathrm{c}, \mathrm{y}}$ & $5.47 \pm 0.46^{\mathrm{b}, \mathrm{z}}$ & $4.16 \pm 0.23^{\mathrm{b}, \mathrm{y}}$ \\
\hline & Cont. & 22 & $17.7 \pm 0.05^{\mathrm{cd}, \mathrm{y}}$ & $2,040.88 \pm 0.55^{\mathrm{a}, \mathrm{z}}$ & $4.08 \pm 0.02^{\mathrm{c}, \mathrm{y}}$ & $5.99 \pm 0.61^{b c, z}$ & $4.50 \pm 0.24^{\mathrm{bc}, \mathrm{y}}$ \\
\hline & $\mathrm{Ch}-\mathrm{Al}$ & 0 & $15.6 \pm 0.10^{\mathrm{a}}$ & $2,207.10 \pm 0.42^{\mathrm{d}}$ & $3.68 \pm 0.03^{\mathrm{a}}$ & $4.67 \pm 0.35^{\mathrm{a}}$ & $3.22 \pm 0.15^{\mathrm{a}}$ \\
\hline & $\mathrm{Ch}-\mathrm{Al}$ & 8 & $15.5 \pm 0.10^{\mathrm{a}, \mathrm{z}}$ & $2,200.59 \pm 0.40^{c, x}$ & $3.99 \pm 0.02^{\mathrm{b}, \mathrm{y}}$ & $4.98 \pm 0.26^{\mathrm{a}, \mathrm{z}}$ & $3.38 \pm 0.23^{\mathrm{a}, \mathrm{z}}$ \\
\hline & $\mathrm{Ch}-\mathrm{Al}$ & 15 & $16.5 \pm 0.05^{\mathrm{b}, \mathrm{z}}$ & $2,181.18 \pm 0.30^{\mathrm{b}, \mathrm{z}}$ & $3.96 \pm 0.01^{\mathrm{b}, z y}$ & $5.15 \pm 0.26^{\mathrm{ab}, \mathrm{z}}$ & $3.50 \pm 0.26^{\mathrm{ab}, \mathrm{z}}$ \\
\hline & $\mathrm{Ch}-\mathrm{Al}$ & 22 & $16.8 \pm 0.10^{\mathrm{bc}, \mathrm{z}}$ & $2,101.31 \pm 0.48^{\mathrm{a}, \mathrm{y}}$ & $3.99 \pm 0.02^{\mathrm{b}, \mathrm{z}}$ & $5.29 \pm 0.31^{\mathrm{b}, \mathrm{z}}$ & $4.01 \pm 0.19^{\mathrm{b}, \mathrm{z}}$ \\
\hline & $\mathrm{Ch}-\mathrm{Ca}$ & 0 & $15.6 \pm 0.10^{\mathrm{a}}$ & $2,207.10 \pm 0.42^{c}$ & $3.68 \pm 0.03^{\mathrm{a}}$ & $4.67 \pm 0.35^{\mathrm{a}}$ & $3.22 \pm 0.15^{\mathrm{a}}$ \\
\hline & $\mathrm{Ch}-\mathrm{Ca}$ & 8 & $16.3 \pm 0.10^{\mathrm{b}, \mathrm{x}}$ & $2,194.65 \pm 0.28^{b, y}$ & $3.90 \pm 0.02^{\mathrm{b}, \mathrm{z}}$ & $4.99 \pm 0.27^{\mathrm{ab}, \mathrm{z}}$ & $3.43 \pm 0.21^{\mathrm{a}, \mathrm{z}}$ \\
\hline & $\mathrm{Ch}-\mathrm{Ca}$ & 15 & $16.5 \pm 0.10^{\mathrm{bc}, \mathrm{z}}$ & $2,146.14 \pm 0.19^{\mathrm{a}, \mathrm{y}}$ & $3.93 \pm 0.02^{\mathrm{b}, \mathrm{z}}$ & $5.37 \pm 0.35^{\mathrm{b}, \mathrm{z}}$ & $3.98 \pm 0.27^{\mathrm{b}, \mathrm{zy}}$ \\
\hline \multirow[t]{15}{*}{ 'Regina' } & Cont. & 0 & $17.2 \pm 0.05^{\mathrm{a}}$ & $2,930.46 \pm 0.40^{\mathrm{e}}$ & $3.61 \pm 0.02^{\mathrm{a}}$ & $4.83 \pm 0.22^{\mathrm{a}}$ & $3.17 \pm 0.17^{\mathrm{a}}$ \\
\hline & Cont. & 8 & $18.8 \pm 0.05^{\mathrm{bc}, \mathrm{x}}$ & $2,808.49 \pm 1.19^{\mathrm{d}, \mathrm{z}}$ & $3.65 \pm 0.04^{\mathrm{a}, \mathrm{z}}$ & $4.93 \pm 0.2^{\mathrm{a}, \mathrm{z}}$ & $3.53 \pm 0.17^{\mathrm{ab}, \mathrm{z}}$ \\
\hline & Cont. & 15 & $18.5 \pm 0.10^{\mathrm{b}, \mathrm{x}}$ & $2,718.82 \pm 0.55^{c, z}$ & $3.74 \pm 0.03^{\mathrm{b}, \mathrm{z}}$ & $4.99 \pm 0.08^{\mathrm{ab}, \mathrm{z}}$ & $3.84 \pm 0.18^{\mathrm{b}, \mathrm{z}}$ \\
\hline & Cont. & 22 & $19.3 \pm 0.10^{\mathrm{d}, \mathrm{x}}$ & $2,637.73 \pm 1.50^{\mathrm{b}, \mathrm{z}}$ & $3.93 \pm 0.02^{c, y}$ & $5.29 \pm 0.12^{\mathrm{b}, \mathrm{y}}$ & $4.32 \pm 0.16^{\mathrm{c}, z y}$ \\
\hline & Cont. & 28 & $21.2 \pm 0.05^{\mathrm{e}, \mathrm{x}}$ & $2,488.46 \pm 0.42^{\mathrm{a}, \mathrm{z}}$ & $3.99 \pm 0.02^{c, y}$ & $5.51 \pm 0.34^{\mathrm{bc}, \mathrm{y}}$ & $4.55 \pm 0.21^{c, z}$ \\
\hline & Ch-Al & 0 & $17.2 \pm 0.05^{\mathrm{a}}$ & $2,930.46 \pm 0.40^{\mathrm{e}}$ & $3.61 \pm 0.02^{\mathrm{a}}$ & $4.83 \pm 0.22^{\mathrm{a}}$ & $3.17 \pm 0.17^{\mathrm{a}}$ \\
\hline & Ch-Al & 8 & $17.5 \pm 0.10^{\mathrm{ab}, \mathrm{y}}$ & $2,866.06 \pm 0.21^{\mathrm{d}, \mathrm{x}}$ & $3.63 \pm 0.02^{\mathrm{a}, \mathrm{z}}$ & $4.87 \pm 0.17^{\mathrm{a}, \mathrm{z}}$ & $3.36 \pm 0.20^{\mathrm{a}, \mathrm{z}}$ \\
\hline & $\mathrm{Ch}-\mathrm{Al}$ & 15 & $17.3 \pm 0.05^{\mathrm{ab}, \mathrm{y}}$ & $2,802.88 \pm 0.25^{c, x}$ & $3.73 \pm 0.02^{\mathrm{b}, \mathrm{z}}$ & $4.92 \pm 0.31^{\mathrm{a}, \mathrm{z}}$ & $3.76 \pm 0.25^{\mathrm{b}, \mathrm{z}}$ \\
\hline & $\mathrm{Ch}-\mathrm{Al}$ & 22 & $18.6 \pm 0.05^{\mathrm{b}, \mathrm{y}}$ & $2,776.46 \pm 0.68^{\mathrm{b}, \mathrm{x}}$ & $3.77 \pm 0.02^{\mathrm{b}, \mathrm{z}}$ & $4.99 \pm 0.13^{\mathrm{ab}, \mathrm{z}}$ & $4.01 \pm 0.37^{b c, z}$ \\
\hline & $\mathrm{Ch}-\mathrm{Al}$ & 28 & $19.0 \pm 0.10^{c, y}$ & $2,693.36 \pm 0.60^{\mathrm{a}, \mathrm{x}}$ & $3.82 \pm 0.02^{\mathrm{bc}, \mathrm{z}}$ & $5.00 \pm 0.24^{\mathrm{ab}, \mathrm{z}}$ & $4.33 \pm 0.38^{\mathrm{bc}, \mathrm{z}}$ \\
\hline & Ch-Ca & 0 & $17.2 \pm 0.05^{\mathrm{b}}$ & $2,930.46 \pm 0.40^{\mathrm{e}}$ & $3.61 \pm 0.02^{\mathrm{a}}$ & $4.83 \pm 0.22^{\mathrm{a}}$ & $3.17 \pm 0.17^{\mathrm{a}}$ \\
\hline & $\mathrm{Ch}-\mathrm{Ca}$ & 8 & $16.8 \pm 0.05^{\mathrm{a}, \mathrm{z}}$ & $2,828.24 \pm 0.64^{\mathrm{d}, \mathrm{y}}$ & $3.67 \pm 0.02^{\mathrm{a}, \mathrm{z}}$ & $4.88 \pm 0.18^{\mathrm{a}, \mathrm{z}}$ & $3.46 \pm 0.20^{\mathrm{ab}, \mathrm{z}}$ \\
\hline & $\mathrm{Ch}-\mathrm{Ca}$ & 15 & $16.8 \pm 0.05^{\mathrm{a}, \mathrm{z}}$ & $2,749.55 \pm 0.42^{c, y}$ & $3.73 \pm 0.02^{\mathrm{ab}, \mathrm{z}}$ & $5.13 \pm 0.15^{\mathrm{b}, \mathrm{z}}$ & $3.80 \pm 0.19^{\mathrm{b}, \mathrm{z}}$ \\
\hline & $\mathrm{Ch}-\mathrm{Ca}$ & 22 & $17.5 \pm 0.10^{\mathrm{bc}, \mathrm{z}}$ & $2,648.28 \pm 0.60^{b, y}$ & $3.79 \pm 0.01^{\mathrm{b}, \mathrm{z}}$ & $5.27 \pm 0.14^{\mathrm{b}, \mathrm{y}}$ & $4.20 \pm 0.21^{c, z}$ \\
\hline & $\mathrm{Ch}-\mathrm{Ca}$ & 28 & $18.4 \pm 0.10^{\mathrm{c}, \mathrm{z}}$ & $2,557.84 \pm 0.95^{\mathrm{a}, \mathrm{y}}$ & $3.97 \pm 0.02^{\mathrm{c}, \mathrm{y}}$ & $5.33 \pm 0.10^{\mathrm{b}, \mathrm{zy}}$ & $4.51 \pm 0.23^{\mathrm{cd}, \mathrm{z}}$ \\
\hline
\end{tabular}

abdce : post hoc Fisher (LSD) test for storage time; ${ }^{\text {zyx }}$ : post hoc Fisher (LSD) test for threats.

*Storage days.

\section{Antimicrobial activity of the coatings}

The highest microbiological contamination was detected on the control samples (Table 1). Both chitosan-based coatings reduced the microbiological contaminations during the shelf-life period. The effect of the $\mathrm{Ch}-\mathrm{Al}$ coating is higher, but the difference is not significant. From the viewpoint of the coliform bacteria all of the samples were safe during the full period.

\section{CONCLUSIONS}

The chitosan based coatings preserved the sweet cherry quality during its shelf-life period. The Rozalina sweet cherry cultivar was more sensitive for the manipulation and had shorter storage time. Based on the quality and safety parameters the shelf life period for the cultivar 'Rozalina' was $21 \mathrm{~d}$ and for the cultivar 'Regina' was $28 \mathrm{~d}$. The $\mathrm{Ch}-\mathrm{Al}$ bilayer coatings preserved better the antioxidant activity, the crunchiness and the $\mathrm{pH}$, then the $\mathrm{Ch}-\mathrm{Ca}$ coating. 


\section{ACKNOWLEDGEMENT}

This work was supported by the Bulgarian Ministry of Education and Science under the National Research Programme "Healthy Foods for a Strong Bio-Economy and Quality of Life" approved by DCM \# 577/17.08.2018 and by Agriculture Academy of Bulgaria 2019 "TN3: Using of natural components for preparing of functional foods (2019-2021)" WP: "Using of natural polymers, like edible coatings for extension of the fruit shelf-life".

\section{REFERENCES}

Aday, M.S. and Caner, C. (2010). Understanding the effects of various edible coatings on the storability of fresh cherry. Packaging Technology and Science, 23(8): 441-456.

Alique, R., Zamorano, J.P., Martínez, M.A., and Alfonso, J. (2005). Effect of heat and cold treatments on respiratory metabolism and shelf-life of sweet cherry, type picota cv. 'Ambrunés'. Postharvest Biology and Technology, 35: 153-165.

Arnao, M.B., Cano, A., and Acosta, M. (2001). The hydrophilic and lipophilic contribution to total antioxidant activity. Food Chemistry, 73(2): 239-244.

Bautista-Banos, S., Hernández-Lauzardo, A.N., Velázquez-del Valle, M.G., Hernández López, M., Ait Barka, E., Bosquez-Molina, E., and Wilson, C.L. (2006). Chitosan as a potential natural compound to control pre and postharvest diseases of horticultural commodities. Crop Protection, 25: 108-118.

Bellich, B., D'Agostino, I., Semeraro, S., Gamini, A., and Cesàro, A. (2016). "The good, the bad and the ugly" of chitosans. Marine Drugs, 14(5): 99.

Comabella, E. and Lara, I. (2013). Cell wall disassembly and post-harvest deterioration of 'Sweetheart' sweet cherry fruit: involvement of enzymic and non-enzymic factors. Pure and Applied Chemical Sciences, 1: $1-18$.

Conte, A., Scrocco, C., Lecce, L., Mastromatteo, M., Del Nobile, M.A. (2009). Ready-to-eat sweet cherries: Study on different packaging systems. Innovative Food Science \& Emerging Technologies, 10(4): 564571.

Diaz-Mula, H.M., Serrano, M., and Valero, D. (2012). Alginate coatings preserve fruit quality and bioactive compounds during storage sweet cherry fruit. Food Bioprocess Technology, 5: 2990-2997.

Dong, H., Cheng, L., Tan, J., Zheng, K., and Jiang, Y. (2004). Effects of chitosan coating on quality and shelf life of peeled litchi fruit. Journal of Food Engineering, 64: 355-358.

Ferretti, G., Bacchetti, T., Belleggia, A., and Neri, D. (2010). Cherry antioxidants: from farm to table. Molecules, 15: 6993-7005.

García, M., Ventosa, M., Díaz, R., Falco, S., and Casariego, A. (2014). Effects of aloe vera coating on postharvest quality of tomato. Fruits, 69(2): 117-126, https://doi.org/10.1051/fruits/2014001.

Ghasemnezhad, M., Nezhad, M.A., and Gerailoo, S. (2011). Changes in postharvest quality of loquat (Eriobotrya japonica) fruits influenced by chitosan. Horticultural Environmental Biotechnology, 52: 40-45.

Hernandez-Munoz, P., Almenar, E., Del Valle, V., and Gavara, R. (2008). Effect of chitosan coating combined with postharvest calcium treatment on strawberry (Fragaria $\times$ ananassa) quality during refrigerated storage. Food Chemistry, 110: 428-435. 
Hong, K., Xie, J., Zhang, L., Sun, D., and Gong, D. (2012). Effects of chitosan coating on postharvest life and quality of guava (Psidium guajava L.) fruit during cold storage. Scientia Horticulturae, 144: 172-178.

Lin, M.G., Lasekan, O., Saari, N., and Khairunniza-Bejo, S. (2018). Effect of chitosan and carrageenanbased edible coatings on post-harvested longan (Dimocarpus longan) fruits. CyTA - Journal of Food, 16(1): 490-497, https://doi.org/10.1080/19476337.2017.1414078.

Long, L.E., Whiting, M., and Nunez-Elisea, R. (2007). Sweet cherry cultivars for the fresh market. Oregon State Univ., PNW 604.

Maisnam, D., Rasane, P., Dey, A., Kaur, S., and Sarma, C. (2017). Recent advances in conventional drying of foods. Journal of Food Technology and Preservation, 1: 25-34.

Malchev, S. and Zhivondov, A. (2016). Breeding programme for developing new sweet cherry cultivars in the Fruit Growing Institute, Plovdiv, Bulgaria. Agricultural Science and Technology, 8(4): 289-291.

Misir, J., Brishti, F.H., and Hoque, M.M. (2014). Aloe vera gel as a novel edible coating for fresh fruits: a review. American Journal of Food Science and Technology, 2(3): 93-97, https://doi.org/10.12691/ajfst-23-3.

Pasquariello, M.S., Di Patre, D., Mastrobuoni, F., Zampella, L., Scortichini, M., and Petriccione, M. (2015). Influence of postharvest chitosan treatment on enzymatic browning and antioxidant enzyme activity in sweet cherry fruit. Postharvest Biology and Technology, 109: 45-56.

Petriccione, M., De Sanctis, F., Pasquariello, M.S., Mastrobuoni, F., Rega, P., Scortichini, P., and Mencarelli, F. (2015). The effect of chitosan coating on the quality and nutraceuticaltraits of sweet cherry during postharvest life. Food Bioprocess Technology, 8: 394-408.

Serrano, M., Martinez-Romero, D., Castillo, S., Guillén, F., and Valero, D. (2005). The use of natural antifungal compounds improves the beneficial effect of MAP in sweet cherry storage. Innovative Food Science \& Emerging Technologies, 6(1): 115-123.

Usenik, V., Fabcic, J., and Stampar, F. (2008). Sugars, organic acids, phenolic composition and antioxidant activity of sweet cherry (Prunus avium L.). Food Chemistry, 107: 185-192.

Wani, A.A., Singh, P., Gul, K., Wani, M.H., and Langowski, H.C. (2014). Sweet cherry (Prunus avium): Critical factors affecting the composition and shelf life. Food Packaging and Shelf Life, 1(1): 86-99.

Zhivondov, A. (2011). 'Rosalina'-a new bicolor cherry cultivar. In: II Balkan Symposium on Fruit Growing 981, pp. 201-203.

Zsom, T., Zsom-Muha, V., Dénes, D.L., Baranyai, L., and Felföldi, J. (2016). Quality changes of pear during shelf-life. Progress in Agricultural Engineering Sciences, 12(1): 81-106.

Open Access. This is an open-access article distributed under the terms of the Creative Commons Attribution-NonCommercial 4.0 International License (https://creativecommons.org/licenses/by-nc/4.0/), which permits unrestricted use, distribution, and reproduction in any medium for non-commercial purposes, provided the original author and source are credited, a link to the CC License is provided, and changes - if any - are indicated. 